\title{
Sønderjydske Præster \\ fordrevne i Svenskekrigen 1658-59.
}

\section{Ved Erh. Qvistgaard.}

Som bekendt maatte Præsterne, særlig i Sønderjylland, under Svenskekrigen, da Fjenden faldt ind $i$ Landet og for frem med Plyndring, Mord og Brand, ofte flygte fra Præstegaardene, hvor Fjenden mente at finde det største Bytte, og skjule sig i Skove og Moser med Hustruer og Børn, nogle Præster blev endog dræbte. Andre lykkedes det at flygte til Byerne, Ribe og Kolding, hvor de saa forblev, til der igen faldt Ro over Landet.

Her berettes om, hvorledes Biskoppen i Ribe da sammenkaldte disse Præster og gav dem Besked om, hvorledes de der i Byen skulde forholde sig overfor dem af deres Menigheder, der ogsaa vare flygtede til Ribe. Følgende 14 Præster opholdt sig i 1659 i Ribe.

(Frøs Herred). M. Anders i Lintrup, Hr. Bertel i Hjortlund og Hr. Peder i Hygom.

(A n s t Herred). Hr. Hans i Gamst, Hr. Niels i Leirskov.

(Gram Herred). Hr. Frederik i Gram, Hr. Johan i Nustrup.

(H vi d ding H erred). Hr. Peder i Højrup, Hr. Krabbe i Spandet.

(M a It Herred). Hr. Jacob i Maltbæk, Hr. Christen i Bækbølling, Hr. Gregers i Vejen.

(G jørding Herred). Hr. Niels i Aastrup, Hr. Niels i Gjørding.

Anno 1659 den 7. July haffuer Dn. Episcopus i sit Huus convocerit (sammenkaldt) de fremmede Præster, som i denne Tid, dis verre ere fra Kald forjagede oc sig her hos os opholder oc dennem forholdit.

I. om en designation (Fortegnelse) at forfatte aff en huer 
paa sine Sognefolk, som her paa steden findis saavidt mulig.

II. at en huer sine Sognefolk i sygdom med Sacramented vilde betiene, disligiste og saa med de døde at begraffue.

III. Om en tieneste eller prediken at forrette huer Onsdag i Sct. Catharina Kirke, huor de fattige og forjagede aff landit kunde forsamlis oc da ogsaa om communicanter findis, med sakramentet betienis, hvortil de dannemend som forsamlede vaare, suaerede, de saadant altsammen saavidt muligt godvilligen og gierne forrette vilde oc dersom de til deris huse forreisendis vorder vilde de tale med en af deris Herrids Præster, som deris siuge i deris fraværelse skulde betiene.

IV. Haffuer M. Niels Jørgensen Seerup, Pastor til vor Frue Kirke begieret, at Hr. Albert som Froprædiken Prest oc saavidt Medtiener her til Domkirken vilde med sacramented betiene de syge landflygtige som icke haffue egen Sognepræst her paa Staden og begraffue de døde efterdi suaghed tager flux offuerhaand saa hand det icke ene kunde forrette oc den ordinarie capelan oc saa tit kand være forhindret. Hvortil hand suarede, at hand det god villigen $i$ byen og udenfor saa vit mulig oc vilde efterkomme.

Disse Meddelelser findes i Ribe Stifts Landemodeprotokol 1635-64 Fol. 166. 